\title{
NSD1 wt Allele
}

National Cancer Institute

\section{Source}

National Cancer Institute. NSD1 wt Allele. NCI Thesaurus. Code C75877.

Human NSD1 wild-type allele is located within 5q35.2-q35.3 and is approximately $162 \mathrm{~kb}$ in length. This allele, which encodes histone-lysine N-methyltransferase, H3 lysine-36 and H4 lysine-20 specific protein, plays a role in the modulation of histone methylation. Mutations and translocations of the gene are involved in several diseases. 